\title{
ANALISIS LAJU KOROSI BESI BETON DENGAN MEDIUM TANAH RAWA
}

\author{
Rahmaniah $^{1}$, Nurul Amalia ${ }^{1}$, Ihsan $^{1}$ \\ ${ }^{1}$ Jurusan Fisika, Fakultas Sains dan Teknologi, Universitas Islam Negeri Alauddin Makassar \\ email: nia.physics08.uin@gmail.com,nurul.amalia@uin-alauddin.ac.id,ihsanphysics@uin-alauddin.ac.id
}

\begin{abstract}
The research on corrosion rate analysis of concrete iron with swamp soil medium has been conducted. The aims of this study were to determine the corrosion rate and the types of corrosion that occurred in concrete iron with swamp soil medium. The methods of this study are Weight Loss method, Atomic Absorption Spectroscopy (AAS) test, and Scanning Electron Microscope-Energy Dispersion X-Ray (SEM-EDX). This study used a different immersion time variant, such as 20 days, 40 days, 65 days, and without medium for 65 days. The concrete iron used in this study is concrete $\mathrm{U}-24$ or plain concrete iron 10 . The corrosion rate that occurs in iron concrete with swamp soil medium at 20 days immersion is 20977.5868 mmpy, 40 days immersion is 17721.9174 mmpy, 65 days immersion is 16932 . 9071 and 65 days without a medium are $3023.3793 \mathrm{mmpy}$. The more time, the rate of corrosion become more slowly due to the influence of corrosion products that have occurred. The corrosion rate without the medium is slower than the corrosion rate with the medium. The types of corrosion that occurs in concrete iron with swamp soil medium are crevice corrosion and pitting corrosion.
\end{abstract}

Keywords: corrosion rate, concrete iron, swamp soil.

\section{PENDAHULUAN}

Indonesia merupakan negara berkembang dengan laju pertumbuhan penduduk yang kian meningkat, mengakibatkan kebutuhan akan prasarana dan sarana fisik juga semakin meningkat setiap tahunnya. Badan Pusat Statistik (2010 - 2015) mencatat laju pertumbuhan penduduk di Indonesia mencapai $1 \%$ $3 \%$. Tingginya laju pertumbuhan penduduk itu membutuhkan penambahan prasarana dan sarana. Prasarana dan sarana tersebut bangunan-bangunan berupa rumah, gedung, pabrik dan sebagainya. Bangunan-bangunan tersebut tidak hanya berlokasi di kawasan anti mainstream, tetapi juga banyak bangunan yang berlokasi di pantai, daerah rawa, daerah bekas tempat pembuangan sampah, dan sebagainya.

Besi menjadi salah satu kebutuhan yang paling banyak digunakan untuk prasana dan sarana fisik tersebut. Besi adalah unsur yang paling melimpah dibumi karena pada inti bumi sebagian besar terdiri dari paduan besi-nikel dan sekitar $5 \%$ terdapat pada kerak bumi. Besi sebagian besar berada dipermukaan bumi karena adanya pengaruh oksidasi ketika bersentuhan dengan udara. Besi banyak digunakan dari pada logam yang lainnya untuk memproduksi paduan logam. Paduan logam tersebut banyak berupa paduan besi dengan karbon yang 
menjadi elemen utama untuk membuat baja. Paduan logam tersebut seperti besi cor, besi kasar, besi tempa, baja, dan besi beton.

Salah satu pemanfaatan besi yang umum adalah beton bertulang. Beton bertulang digunakan sebagai struktur utama pendukung berdirinya sebuah bangunan. Beton bertulang merupakan kombinasi dari beton dan baja tulangan memberikan kekuatan tarik yang tidak dimiliki beton. Baja tulangan atau yang lebih dikenal dengan besi beton oleh orang awam. Tanpa besi, beton bertulang akan retak dengan mudah akibat gangguan-gangguan kecil seperti transportasi yang lewat.

Penggunaan besi beton sebagai bahan konstruksi banyak digunakan karena tidak memerlukan biaya pemeliharaan yang tinggi, dapat bangunan yang kokoh dan ekonomis. Bahan baku besi beton adalah billet. Besi beton yang banyak dipilih oleh masyarakat untuk pembangunan rumah adalah besi beton polos atau besi U-24. Salah satu kelemahan besi adalah mudah mengalami korosi.

Korosi atau pengkaratan adalah pengerusakan material yang disebabkan oleh pengaruh lingkungan dan sekitarnya. Selain itu, pembangunan sekarang banyak dilakukan di lingkungan korosif dan banyak pekerja tidak mengetahui bangunan yang rusak dan roboh tersebut diakibatkan oleh korosi. Lingkungan korosif adalah lingkungan yang terdapat banyak zat korosif yang dapat menyebabkan terjadinya korosi karena kondisi lingkungan fisik (air, tanah, udara) yang mengalami pencemaran dan dipengaruhi oleh $\mathrm{pH}$ lingkungan tersebut. $\mathrm{pH}$ lingkungan dapat berubah akibat dari peristiwa alam seperti di daerah rawa. Daerah rawa memiliki pH sekitar 4,5 akibat rawa yang airnya selalu tergenang.

Luas lahan rawa di Indonesia diperkirakan mencapai 33,39 juta Hektar. Secara garis besar, rawa dominan ada di empat pulau besar yaitu Sumatera, Kalimantan, Papua dan sebagian kecil Sulawesi (Pusdatarawa, 2017). Sulawesi Selatan khususnya dibeberapa kabupaten/kota memiliki lahan rawa. Salah satunya yang memiliki lahan rawa di Sulawesi Selatan terdapat di Danau Mawang kabupaten Gowa. Melihat hal tersebut perlu diketahui kondisi tanah rawa terhadap korosi yang terjadi pada besi beton agar memberikan informasi terhadap masyarakat sekitar.

Penelitian yang dilakukan Sulistyoweni W (2002), mengenai analisa laju korosi pada tulangan beton dengan merendam tulangan beton (St 37) selama 60 hari ke dalam air rawa tercemar dengan perlakuan digerakkan naik turun secara periodik dalam rendaman sehingga besarnya laju korosi adalah 37,59 mpy. Berdasarkan uraian diatas, maka perlu dilakukan penelitian mengenai Analisis Laju Korosi Besi Beton dengan Medium Tanah Rawa dengan menggunakan metode weight loss.

\section{METODE PENELITIAN Alat dan Bahan}

Alat yang digunakan pada penelitian ini adalah gurinda, gergaji besi, mistar, jangka sorong digital, sekop, toples plastik, meteran,gelas kimia, bulp, pipet skala, corong, tabung ukur, labu semprot, spatula, lemari asap, hot plate, neraca analitik, Atomic Absorption Spectrophotometry (AAS) Varian AA240FS, 4 in 1 Soil Survey Instrument, Scanning Electron Microscope - Energy dispersion $X$-Ray (SEM-EDX) dan X-Ray Flourecence (XRF)

Bahan yang digunakan pada penelitian ini adalah besi beton polos, amplas, waterone, $\mathrm{HN}_{3} 65 \%, \mathrm{HClO}_{4} 60 \%$, Standar Magnesium (Mg), Standar Kalium (K), Standar Kalsium ( $\mathrm{Ca})$, Standar Besi (Fe), tanah rawa, kertas saring, tissue, batu didih dan aluminium foil. 


\section{Prosedur Penelitian \\ Preparasi sampel}

Besi beton polos dipotong dengan menggunakan gergaji besi menjadi 15 bagian dengan panjang tiap bagian sebesar $3 \mathrm{~cm}$ yang telah diukur menggunakan mistar Besi yang telah dipotong kemudian diamplas sampai terlihat mengkilap. Selanjutnya besi dicuci menggunakan waterone untuk menghilangkan serbuk-serbuk dari besi yang telah diamplas dan dikeringkan. Setelah itu, mengukur diameter dan tinggi besi menggunakan jangka sorong digital dikarenakan setelah diamplas besi akan mengalami perubahan diameter dan panjang.

\section{Preparasi Medium}

Mengambil tanah rawa di Danau Mawang kabupaten Gowa, Sulawesi Selatan sebanyak 6 titik yaitu titik $A$, titik $B$, titik $C$, titik $D$, titik $E$ dan titik $F$. Jarak antara titik satu dengan titik yang lainnya \pm 100 meter. Mengukur kedalam tanah yang diambil tiap titik dari permukaan air ke tanah. Memisahkan tanah dengan lumpur. Kemudian meletakkan tanah yang telah diambil kedalam toples untuk setiap titik.Kemudian pisahkan sebagian tanah untuk digabungkan menjadi satu. Untuk tanah titik $A$ dan titik $D$ digabungan, titik $B$ dan titik $E$ digabungkan, dan untuk titik $\mathrm{C}$ dan titik $\mathrm{F}$ digabungkan.

\section{Pengujian Kandungan Logam pada Tanah}

\section{- Destruksi basah}

Tanah yang telah digabungkan sehingga total 3 sampel tanah menjadi 6 sampel tanah yang akan menjadi 6 larutan yaitu $A, B, C, D, E$, dan $F$. Menyediakan 6 gelas kimia yang dilabel dengan huruf A, B, C, D, E dan F. Menimbang sampel tanah sebesar 5 gram untuk tiap gelas kimia dengan menggunakan neraca analitik 2 digit.Mencampurkan $100 \mathrm{ml}$ waterone pada tiap sampel tanah yang telah ditimbang.Menambahkan batu didih, $5 \mathrm{ml} \mathrm{HNO}_{3}$ konsentrasi $65 \%$ untuk tiap sampel tanah.Memanaskan sampel tanah hingga $50 \mathrm{ml}$ menggunakan hot plate Setelah $50 \mathrm{ml}$, dinginkan sampel tanah kemudian tambahkan $1 \mathrm{ml} \mathrm{HClO}_{4}$ konsentrasi $60 \%$ tiap sampel tanah. Memanaskan kembali sampel tanah hingga $20 \mathrm{ml}$ kemudian dinginkan. Setelah sampel tanah dingin, saring sampel tanah menggunakan kertas saring ke tabung takar $100 \mathrm{ml}$ dengan menambahkan waterone secukupnya hingga mencukupi $100 \mathrm{ml}$.

- Proses Larutan Standar

Larutan standar yang dibuat yaitu magnesium (Mg), kalium (K), kalsium (Ca) dan Besi (Fe). Menyediakan 5 buah tabung takar $50 \mathrm{ml}$, pipet tetes $25 \mathrm{ml}$ dan gelas kimia $300 \mathrm{ml}$. Tabung takar diberi label 5 ppm, 10 ppm, 15 ppm, 20 ppm, dan 25 ppm. Mengencerkan larutan induk 100 ppm menjadi 5 ppm yaitu dengan memipet $2,5 \mathrm{ml}$ larutan induknya kemudian memasukkan ke dalam tabung takar $50 \mathrm{ml}$. Setelah itu masukkan waterone sampai batas pada tabung takar. Untuk $10 \mathrm{ppm}$ memipet sebanyak $5 \mathrm{ml}$ larutan induk lalu dimasukkan dalam tabung takar $50 \mathrm{ml}$. Setelah itu masukkan waterone sampai batas pada tabung takar. Melakukan hal yang sama dengan 15 ppm, 20 ppm, dan 25 ppm dengan menggunakan rumus pengenceran. Setelah itu, melakukan pengujian logam magnesium (Mg) dengan menggunakan alat Atomic Absorption Spectrophotometry (AAS). Lakukan hal yang sama dengan kalium (K) dengan 3 ppm, 6 ppm, 9 ppm, 12 ppm, dan 15 ppm; kalsium (Ca) dengan 10 ppm, 20 ppm, 30 ppm, 40 ppm, dan 50 ppm; besi ( $F e$ ) dengan 10 ppm, 20 ppm, 30 ppm, 40 ppm dan 50 ppm.

- Persiapan injek ke alat Atomic Absorption Spectrophotometry (AAS)

Menyiapkan larutan blanko, medium dan larutan standar secara berurut. Mengoperasikan alat dan mengoptimalkan sesuai petunjuk alat untuk pengukuran magnesium (Mg). Mengaspirasikan larutan blanko ke dalam AAS- 
Nyala kemudian mengatur serapan nol. Mengaspirasikan larutan standar satu persatu ke dalam alat AAS-Nyala kemudian mencatat nilai absorbansi yang muncul pada layar komputer dengan panjang gelombang 202,6 nm. Membuat kurva kalibrasi dari nilai-nilai absorban yang diperoleh. Melakukan hal yang sama untuk sampel medium yang diuji. Setelah semua sampel medium telah diuji maka mengulangi pengukuran untuk kalium (K) dengan panjang gelombag 409,4 nm, kalsium (Ca) dengan panjang gelombang 239,9 nm, dan besi ( $\mathrm{Fe}$ ) dengan panjang gelombang $217 \mathrm{~nm}$.

\section{Pengujian Laju Korosi}

Menimbang besi yang telah dibersihkan untuk menentukan massa awal menggunakan neraca analitik 4 digit. Kemudian besi direndam pada medium tanah rawa selama 20 hari, 40 hari, dan 65 hari pada suhu ruang dan 65 hari tanpa perendaman pada suhu ruang. Setelah 20 hari, 40 hari, dan 65 hari sampel diangkat dan dilakukan pembersihan produk korosi dan mencuci dengan waterone. Setelah kering dilakukan penimbangan akhir untuk mengetahui kehilangan massa pada sampel. Selanjutnya mencatat hasilnya pada tabel pengamatan. Pengujian Scanning Electron Microscope (SEM)

Pengujian Scanning Electron Microscope (SEM) adalah pengujian untuk menentukan jenis korosi yang terjadi dengan mengetahui morfologinya. Pengujian ini dilakukan di Pusat Penelitian Fisika-Lembaga IImu Pengetahuan Indonesia (P2F-LIPI) kawasan Pusat Penelitian IImu Pengetahuan dan Teknologi (Puspitek).

\section{HASIL PENELITIAN}

\section{Konsentrasi Tanah}

Berdasarkan penelitian yang dilakukan Sulistyoweni W (2002), dalam air rawa dimungkinkan terdapat bakteri anaerob seperti D.desufulriconse. Bakteri tersebut merupakan bakteri penyebab terjadinya korosi.Tanah rawa yang digunakan memiliki $\mathrm{pH}$ tanah sebesar 4,5 sampai dengan 5,5. Tanah rawa dilakukan pengujian kandungan unsur-unsur tersebut. Untuk mengetahui unsurunsur tersebut maka dilakukan pengujian dengan metode Atomic Absorption Spectrophotometer (AAS). Berikut disajikan dalam bentuk tabel dibawah ini.

Tabel 1. Kadar unsur logam dalam tanah rawa

\begin{tabular}{|c|c|}
\hline Unsur & $\begin{array}{c}\text { Kadar dalam tanah rawa } \\
\text { (ppm) }\end{array}$ \\
\hline Magnesium & 22,4710 \\
\hline Kalium & 14,3571 \\
\hline Besi & 247,9603 \\
\hline Kalsium & 28,5111 \\
\hline
\end{tabular}

Pada tabel 1, tanah rawa memiliki unsur besi yang tinggi dibandingkan dengan unsur magnesium, kalium, dan kalsium. Unsur besi dapat menjadi media pengkorosi dimana ion ini berionisasi dan menempel dengan besi beton sehingga terjadinya korosi namun ada juga unsur besi yang ionnya terlepas dan terurai dengan tanah rawa. Namun, untuk magnesium, kalium dan kalsium dalam tanah rawa memiliki kadar yang rendah. Sehingga tidak memiliki pengaruh yang besar terhadap korosi yang terjadi. 


\section{Laju Korosi}

Waktu perendaman yang dilakukan terbagi atas 20 hari, 40 hari dan 65 hari pada medium tanah rawa. Nilai laju korosi seperti pada table 2 diperoleh dengan menggunakan persamaan berikut:

Keterangan :

$$
v=\frac{K \times \Delta m}{\rho \times A \times t}
$$

$v$ : Laju korosi (mm/tahun)

$m \quad$ : Massa yang hilang (gram)

$\rho:$ Massa jenis $\left(\mathrm{gram} / \mathrm{cm}^{3}\right)$

$A$ : Luas permukaan sampel $\left(\mathrm{cm}^{2}\right)$

$t$ : Lama waktu perendaman (detik)

Tabel 2. Hasil pengamatan laju korosi besi beton polos

\begin{tabular}{||c|c|c|c|c|c||}
\hline Sampel & $\begin{array}{c}\text { Luas } \\
\text { permukaan } \\
\left(\mathbf{m m}^{2}\right)\end{array}$ & $\begin{array}{c}\text { Densitas } \\
\left(\mathbf{g r a m} / \mathbf{m m}^{\mathbf{3}}\right)\end{array}$ & $\begin{array}{c}\text { Kehilangan } \\
\text { massa } \\
(\mathbf{g r a m})\end{array}$ & $\begin{array}{c}\text { Laju } \\
\text { Korosi } \\
(\mathbf{m m p y})\end{array}$ & $\begin{array}{c}\text { Umur } \\
\text { besi } \\
\text { (tahun) }\end{array}$ \\
\hline A1 & 902,156 & 0,008 & 0,094 & $20.977,587$ & 7,6152 \\
\hline A2 & 912,276 & 0,008 & 0,156 & $17.721,917$ & 9,0313 \\
\hline A3 & 896,925 & 0,008 & 0,257 & $16.932,907$ & 9,2645 \\
\hline A4 & 932,744 & 0,008 & 0,042 & $30.23,379$ & 53,1467 \\
\hline
\end{tabular}

Keterangan : $\mathrm{A} 1=$ perendaman 20 hari, $\mathrm{A} 2=$ perendaman 40 hari, $\mathrm{A} 3=$ perendaman 65 hari, $A 4=65$ hari tanpa perendaman

Pada tabel 2 dijelaskan bahwa besi beton dengan medium tanah rawa 20 hari perendaman dengan luas permukaan 902,156 $\mathrm{mm}^{2}$ diperoleh umur besi 7,6152 tahun jika laju korosi yang terjadi pada besi beton tersebut konstan yaitu sebesar $20.977,587$ mmpy.

Grafik 1. Laju Korosi pada besi beton polos

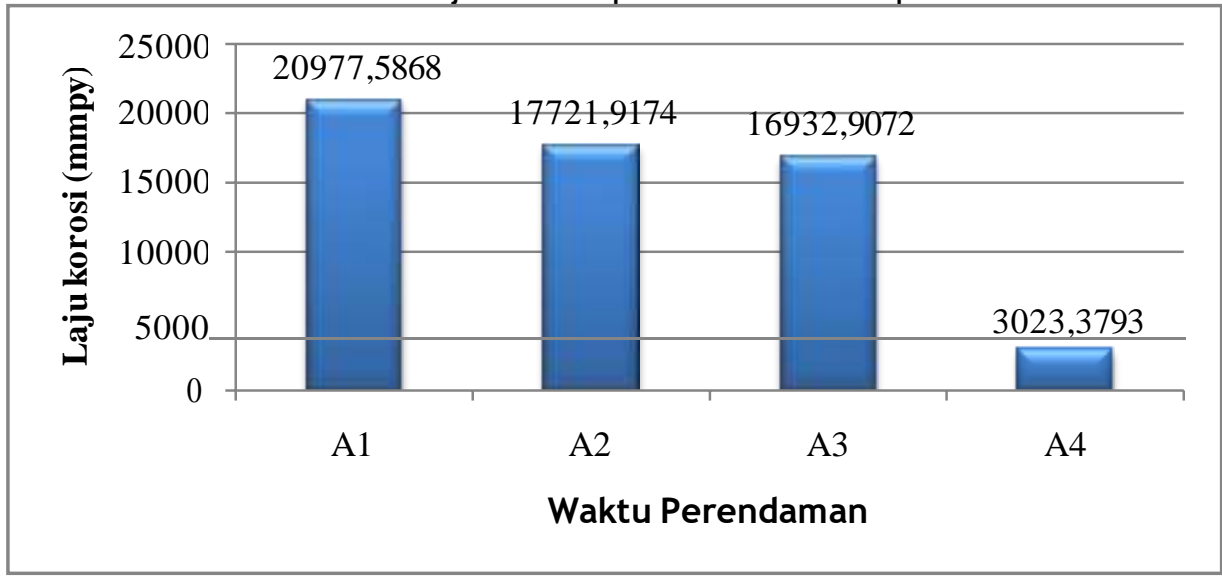

Keterangan : $\mathrm{A} 1=$ Perendaman 20 hari, $\mathrm{A} 2=$ Perendaman 40 hari, $\mathrm{A} 3=$ Perendaman 65 hari, $\mathrm{A} 4=$ Tanpa Perendaman 65 hari. 
Pada grafik 1, menunjukkan laju korosi yang direndam selama 20 hari pada tanah rawa yang terjadi sebesar $20.977,5868$ mmpy. Namun, untuk sampel berikutnya yaitu perendaman 40 hari dan 65 hari terjadi penurunan laju korosi. Hal ini disebabkan karena produk korosi yang dihasilkan semakin lama akan mengalami penebalan dan menyebabkan bagian luas permukaan besi beton yang belum terkorosi menjadi tertutup yang mengakibatkan laju korosi mengalami penurunan dengan bertambahnya waktu perendaman. Untuk perendaman 65 hari tanpa perendaman memiliki laju korosi sebesar 3.023,3793 mmpy lebih rendah dibandingkan dengan yang lainnya karena media untuk terjadinya korosi tidak ada dan didukung dengan tidak adanya kontak langsung dengan udara terbuka yang mengakibatkan korosi melambat.

Pada sampel A1 sebelum dilakukan perendeman selama 20 hari pada tanah rawa terlebih dahulu dilakukan penimbangan untuk massa awal sebesar 12,9685 gram dan setelah direndam selama 20 hari dengan medium tanah rawa, dilakukan pembersihan produk korosi dan ditimbang kembali untuk massa akhir sebesar 12,8750 gram sehingga kehilangan massa sebesar 0,0935 gram yang merupakan produk korosi. Kehilangan massa yang didapatkan terjadi karena logam seperti besi beton akan selalu menyesuaikan diri dengan lingkungannya untuk mencapai kestabilan, sehingga ketika logam berada dalam udara akan melepaskan elektron dan elektron tersebut akan ditangkap dan bereaksi dengan uap air yang berada pada tanah rawa.Untuk sampel A4 yang memiliki kehilangan massa yang sedikit akibat tidak adanya media terbesar penyebab korosi dan didukung oleh wadah yang hanya menggunakan suhu ruang.

Hasil perhitungan laju korosi untuk sampel besi beton polos secara umum dari waktu perendaman 20 hari, 40 hari, 65 hari dan 65 hari tanpa perendaman didapatkan nilai laju korosi yang mengalami penurunan dan untuk kehilangan massa masing-masing sampel mengalami kenaikan yang signifikan secara kontinu kecuali sampel yang berada pada 65 hari tanpa perendaman karena tidak adanya media terbesar pendukung terjadinya korosi. Hal ini terjadi akibat produk karat yang dihasilkan setelah 20 hari akan menghambat kontak langsung besi beton dengan tanah rawa sehingga laju korosi mengalami penurunan setiap betambahnya waktu walaupun produk korosi yang dihasilkan semakin besar tetapi tidak mengalami perubahan secara konstan, seperti ditunjukkan pada grafik 3.

Grafik 2. Perubahan massa pada besi beton polos

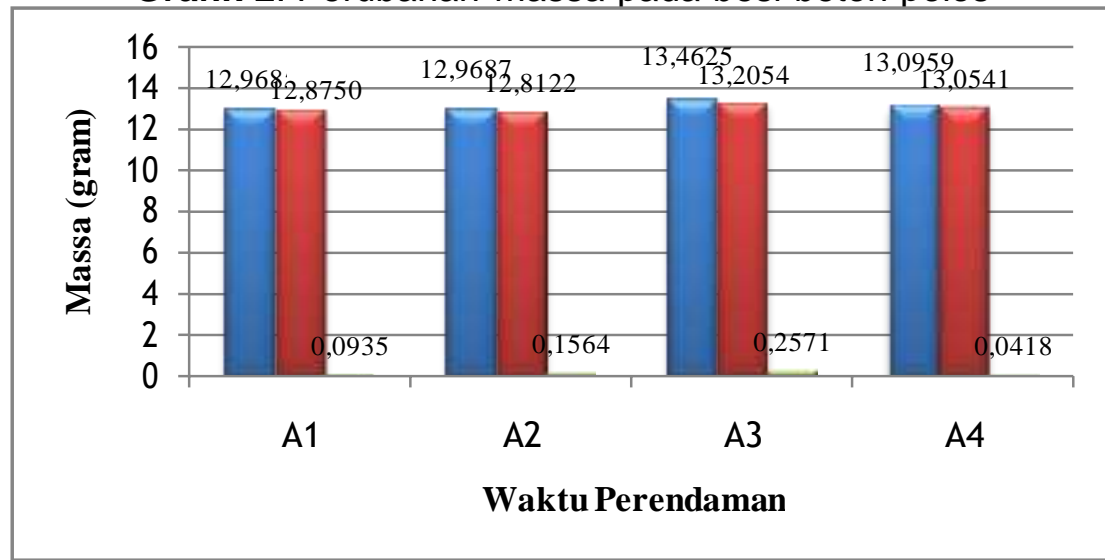

Keterangan : 
Grafik 3. Hubungan laju korosi dengan kehilangan massa pada besi beton polos untuk perendaman

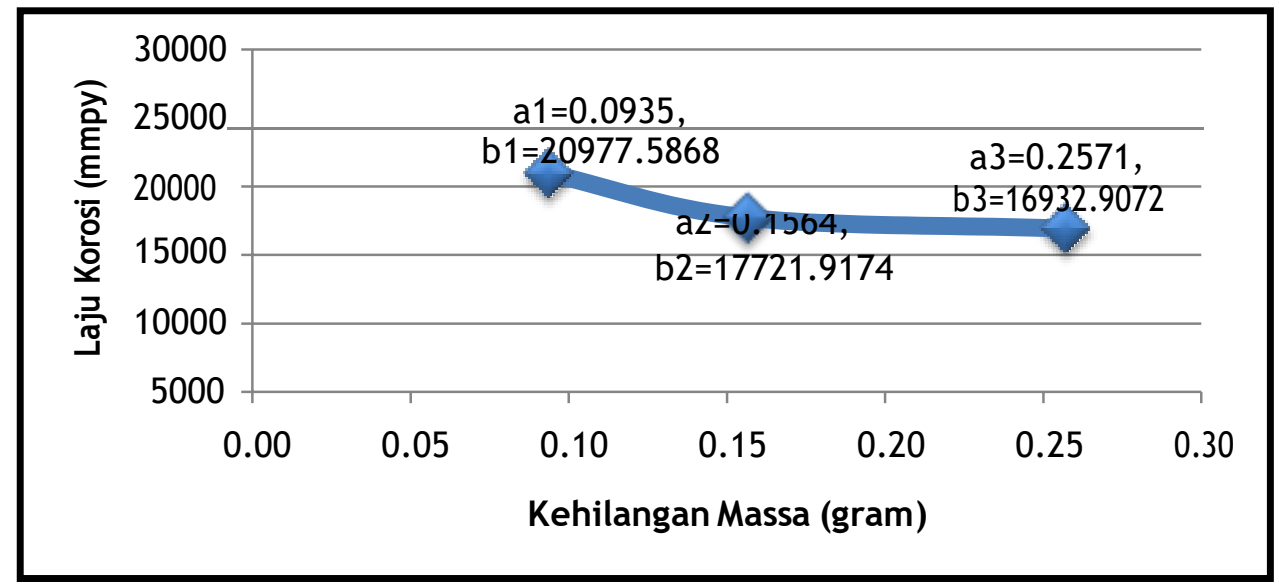

Keterangan : a1,a2,a3 = kehilangan massa; b1, b2, b3 = laju korosi $a 1, b 1=A 1 ; a 2, b 2=A 2 ; a 3, b 3=A 3$.

Berdasarkan grafik 3, dapat dilihat bahwa laju korosi mengalami penurunan dan untuk kehilangan massa mengalami kenaikan. Hal ini terjadi karena produk korosi yang telah terjadi selama 20 hari menghambat kontak langsung dengan tanah rawa sehingga laju korosi semakin menurun setiap betambahanya waktu perendaman. Walaupun kehilangan massa mengalami kenaikan akan tetapi kenaikan yang terjadi tidak secara konstan. Berbeda dengan korosi yang terjadi ketika ada medium dan tanpa medium dapat ditunjukkan pada grafik 4 .

Grafik 4. Hubungan laju korosi dengan kehilangan massa pada besi beton yang perendaman dan tidak perendaman

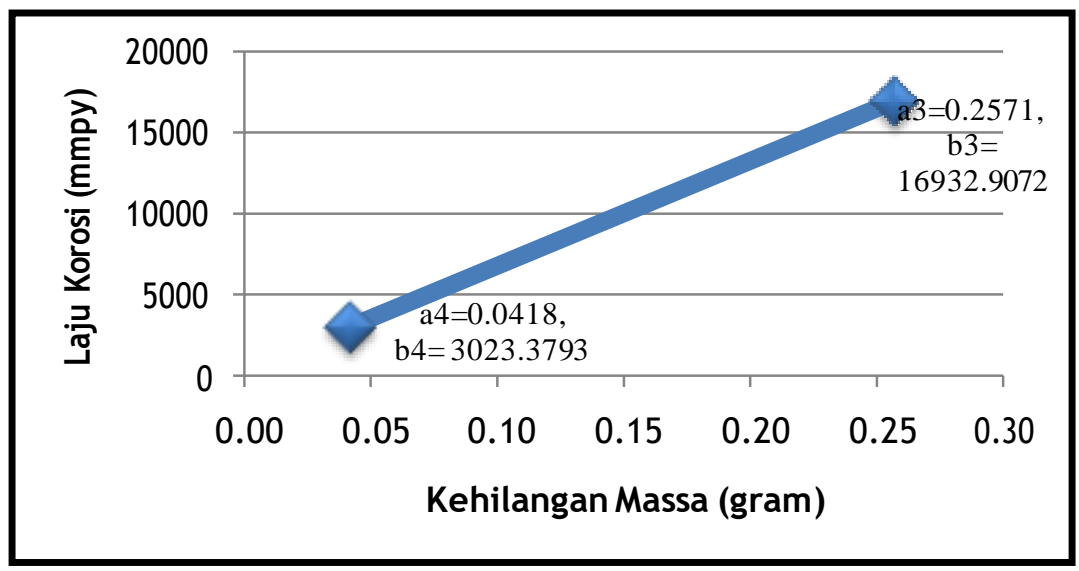

Keterangan : a3,a4 = kehilangan massa; b3,b4 = laju korosi; $\mathrm{a} 3, \mathrm{~b} 3=\mathrm{A} 3 ; \mathrm{a} 4, \mathrm{~b} 4=\mathrm{A} 4$.

Berdasarkan grafik 4 dapat dilihat laju korosi mengalami penurunan dan untuk kehilangan massa juga mengalami penurunan. Hal ini terjadi karena sampel A4 tidak memiliki medium korosif dan berada pada suhu ruang sehingga tidak mengalami proses oksidasi walaupun terdapat produk korosi tetapi korosi yang dihasilkan sedikit akan melambatnya proses korosi itu sendiri. Perbedaan 
lajk korosi yang terjadi antara sampel A1, A2, A3 dan A4 akibat mediumnya. Tanah rawa merupakan medium yang digunakan pada penelitian ini. Tanah rawa yang digunakan memiliki $\mathrm{pH}$ sebesar 5 yang berarti tanah rawa bersifat asam yang menjadi salah satu faktor penyebab terjadinya korosi. Tanah rawa juga memiliki bakteri anaerob yang dapat menyebabkan terjadinya korosi dan memiliki unsure yang dapat mempengaruhi terjadinya korosi yaitu besi $(\mathrm{Fe})$ yang memiliki kadar yang tinggi pada tanah.

\section{Hasil Uji Scanning Electron Microscopy - Energy Dispersion X-Ray (SEM- EDX)}

Gambaran mengenai morofologi dari besi beton yang mengalami korosi dan besi beton yang tidak mengalami korosi dengan menggunakan SEM. Sehingga dapat mengetahui jenis korosi yang terjadi pada besi beton dengan medium dan tanpa medium. Besi beton yang dilakukan pengujian SEM yaitu besi beton dengan medium 65 hari perendaman. Berikut gambar yang yang dapat diamati melalu hasil foto SEM.

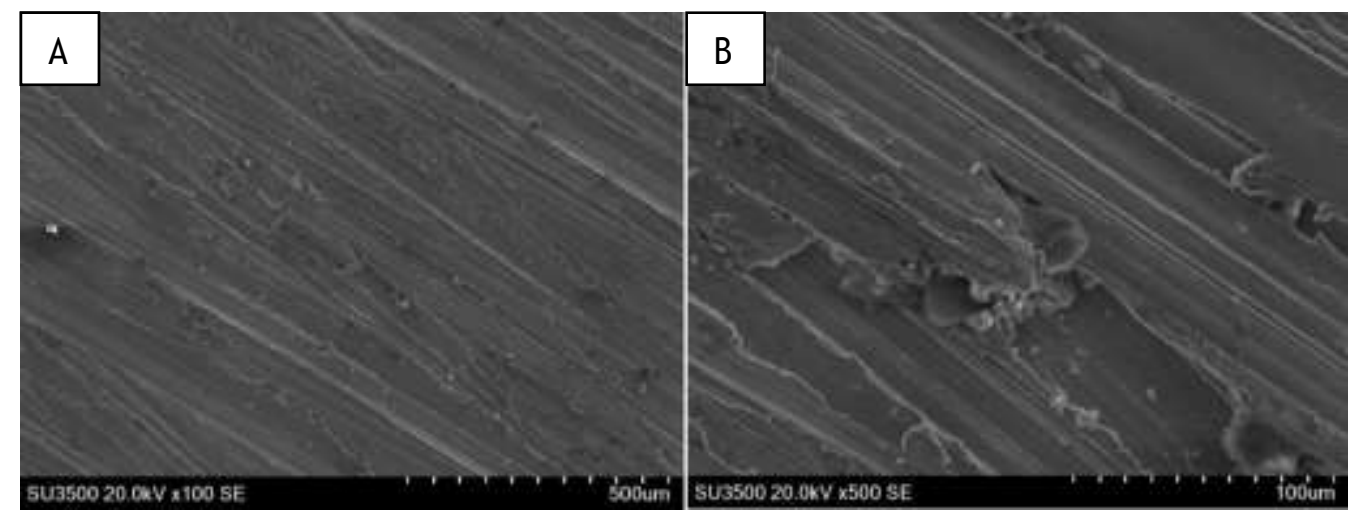

Gambar 1. Foto SEM pada besi beton tanpa medium (A) perbesaraan 100X, (B) perbesaran 500X.

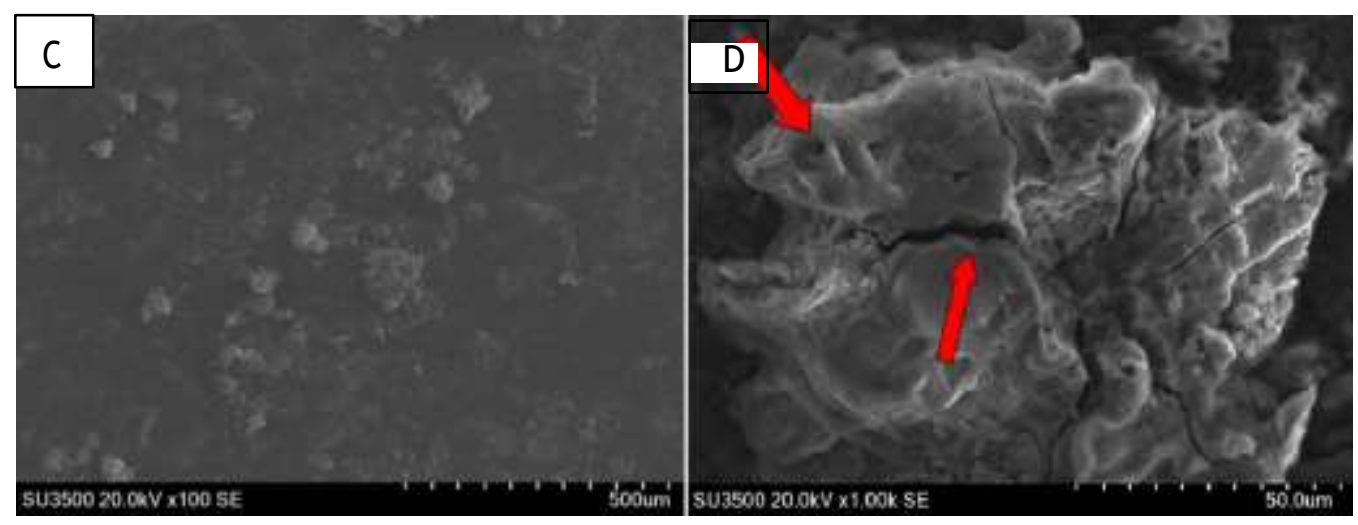

Gambar 2. Foto SEM pada besi beton dengan medium (C) perbesaran 100X, (D) perbesaran 1000X. 
Gambar (C) dan gambar (D) merupakan gambaran besi beton dengan medium 65 hari perendaman. Gambar (A) dan gambar (B) merupakan gambar potongan besi beton tanpa adanya perlakuan untuk terjadinya korosi. Gambar (C) dengan perbesaran 100X terjadi perubahan penampilan dengan adanya produk korosi berbeda dengan gambar $(A)$ dengan perbesaran gambar yang sama dan gambar (B) dengan perbesaran 500X, karena besi beton tersebut merupakan potongan yang dimaksudkan sebagai perbandingan dengan sampel yang mengalami korosi. Menurut Ainulrizal Helmi (2015) dalam penelitiannya mengenai korosi yang terjadi pada stainless steel dengan medium air nira lontar terjadi rengkahan-rengkahan antar partikel dan akibatnya pori-pori semakin melebar dan mudah diterobos oleh atom-atom pengkorosif, jika ini dibiarkan terus menerus spesimen akan terjadi pengeroposan yang mengakibatkan terjadinya korosi sumuran dan korosi celah. Hal ini sama dengan gambar (D) dengan perbesaran 1000X, ditunjukan dengan retakan-retakan yang terjadi pada permukaan besi beton serta adanya lubang. Jenis korosi yang terlihat pada gambar (C) dan gambar (D) yaitu korosi sumuran (pitting corrosion) dan korosi celah (crevice corrosion). Ditunjukkan denga permukaan besi beton yang mengalami keretakan dan berlubang akibat korosi.

Tabel 3. Hasil uji SEM-EDX mapping pada besi beton polos

\begin{tabular}{|c|c|c|}
\hline \hline No & $\begin{array}{c}\text { Perlakuan pada besi } \\
\text { beton }\end{array}$ & Unsur \\
\hline \hline 1 & Tanpa perlakuan & $\mathrm{Si}, \mathrm{Fe}, \mathrm{O}$ \\
\hline 2 & $\begin{array}{c}\text { Menggunakan medium } \\
\text { tanah rawa selama 65 hari }\end{array}$ & $\mathrm{Al}, \mathrm{Cl}, \mathrm{Fe}, \mathrm{O}, \mathrm{Si}, \mathrm{S}$ \\
\hline
\end{tabular}

Berdasarkan hasil EDX mapping pada besi beton tanpa perlakuan terdapat unsure besi (Fe), oksigen (O), dan silika (Si). Untuk besi beton yang mengalami pengkaratan menggunakan medium tanah rawa selama 65 hari di tunjukkan hasil EDX mapping adanya penambahan unsur yaitu alumunium (Al), klorida $(\mathrm{Cl})$, dan sulfur $(\mathrm{S})$. Klorida $(\mathrm{Cl})$ dan sulfur (S) merupakan unsure asam sehingga dapat menyebabkan terjadinya korosi. Adanya pengurangan unsure besi ( $\mathrm{Fe})$ pada besi beton yang berarti terjadi pelepasan elektron dan penambahan unsur oksigen (O) pada besi beton yang berarti terjadi penangkapan elektron. Hal ini ditunjukan dengan adanya perbedaan warna pada besi beton yang tidak mengalami pengkaratan dan besi beton yang mengalami pengkaratan. Besi beton yang tidak mengalami pengkaratan, unsur besi ( $\mathrm{Fe})$ lebih terang dibandingkan besi beton yang mengalami pengkaratan. Begitu pula pada besi beton yang tidak mengalami pengkaratan, unsur oksigen (O) memilik warna yang lebih gelap dibandingkan besi beton yang mengalami pengkaratan.

\section{SIMPULAN}

Adapun simpulan pada penelitian ini adalah tanah rawa memiliki $\mathrm{pH} 4,5$ hingga 5,5 berarti tanah bersifat asam yang mengakibatkan laju korosi pada besi beton U-24 atau besi beton polos semakin cepat dibandingan dengan besi beton tanpa medium. Medium yang digunakan tanah rawa juga mengandung dimungkinkan mengandung mikroba yang dapat mempengaruhi laju korosi. Sehingga hasil laju korosi pada sampel yang menggunakan medium sebesar 20.977,5868 mmpy; 17.721,9174 mmpy; 16.932,9072 mmpy dan untuk laju korosi yang dihasilkan tanpa medium sebesar 3.023,3793 mmpy. Korosi yang 
terjadi pada besi beton yang dengan medium 65 hari perendaman yaitu korosi sumuran (pitting corrosion) dan korosi celah (crevice corrosion).

\section{DAFTAR PUSTAKA}

Afandi, Yudha Kurniawan, dkk. Analisa Laju Korosi pada Pelat Baja Karbon dengan Variasi Ketebalan Coating. Jurnal Teknik. Vol 4 No1 (2015): 1-5.

ASTM Internasional. (2004). ASTM G31-72: Standar Practice for Laboratory Immersion Corrosion Testing Of Metals. United State

Besi. "Ensiklopedai Bebas". http://budisma.net/2015/03/pengertian-ciri-dan-sifatbesi.html ( diakses 10 Juli 2018)

Besi beton. "Ensiklopedai Bebas". https://www.besibeton.net/products/besibeton-polos-sni-10mm/(diakses 10 Juli 2018)

Besi Beton. "Ensiklopedai Bebas". https://nikifour.co.id/mengenal-besi-beton-danmemilih-kualitas-terbaik/ (diakses 09 Juli 2018)

Chang, Raymond. (2005). Kimia Dasar Edisi Ketiga Jilid 2. Jakarta : Erlangga.

Fontana, Mars Guy. 1986. Corrosion Engineering. Singapore : McGraw-Hill Book Co.

Gapsari, Femiana. 2017. Pengantar Korosi. Malang : UBMedia

Haryono, G. 2010. Ekstrak Bahan Alam sebagai Inhibitor Korosi. Jurnal. Vol. 16 (1): 1-6.

J.,Trethewey, KR. 1991. Korosi . Jakarta : PT. Gramedia Pustaka Utama.

Kementrian Agama R.I., "Mushaf An-Nazhif Edisi Terjemahan Tajwid”,Surakarta: PT. Tiga Serangkai. 2014

Khiatuddin, Maulida. 2003. Melestarikan Sumberdaya air dengan Teknologi Rawa Buatan. Yogyakarta:Gadjah Mada University Press

Knofel, Dietbert. 1978. Corrosion Of Building Material . United States : Van Nostrand Reinhold Company Chamberlain.

Notohadiprawiro, Tejoyuwono. 2006. Tanah dan Lingkungan. Repro:Ilmu Tanah Universitas Gaja Mada

Prameswari, Bunga. 2008. Studi Efektifitas Lapis Galvanis Terhdapa Ketahanan Korosi Pipa Baja ASTM A53 Di Dalam Tanah (Underground Pipe). Skripsi Fakultas Teknik Unvesitas Indonesia. Jakarta

Permadi, Lingga Bayu dan Aisyah Endah Palupi. Analisa Laju Korosi Pada Baja Karbon Ringan (Mild Steel) Dengan Perlakuan Bending Pada Media Pengkorosi Larutan. JTM. Vol 3 No 1(2014): 49-54.

Priyotomo, Gadang. 2018. Kamus Saku Korosi Material. Banten : Puspiptek.

Rawa. "Ensiklopedai Bebas". http://www.g-excess.com/pengertian-rawa-atautanah-rawa.html (diakses 11 Juli 2018)

Republik Indonesia. 1991. "Peraturan Pemerintah No.27 Tahun 1991 tentang Rawa". Sekretaris Negara. Jakarta

Sam,Alimuddin. Analisa Kecepatan Korosi Pipa Galvanis Pada Tanah Dengan Tingkat Kehalusan yang Berbeda. Jurnal Teknik Mesin. Vol.3 No.4 (2005)

Shihab, M.Quraish. 2003. Tafsir Al-Mishbah Vol 14. Jakarata : Lentera Hati

Shihab, M.Quraish. 2004. Tafsir Al-Mishbah Vol 8. Jakarata : Lentera Hati

Shihab, M. Quraish. 2009. Tafsir Al Mishbah Vol 9. Jakarta : Lentera Hati

Sidiq, M.Fajar. Analisa Korosi dan Pengendaliannya. Jurnal Foundry Vol. 3 No. 1 (2013):25 -30.

Sudarti, Tety. Mekanisme Inhibisi Korosi Baja Karbon Dalam Lingkungan Airs Sadah. Jurnal. Vol 1 No.2 (2014):16-31.

Syabatini, Annisa. 2009. Analisis Cd dan Cu dengan metode Spektrofotometri Serapan Atom. Jurnal AAS 
Tanah Rawa. "Ensiklopedai Bebas". https://geografi.sobatmateri.com/pengertianciri-jenis-dan-manfaat-rawa/ (diakses 11 Juli 2018)

Tanah Rawa. "Ensiklopedai Bebas". https://portal-ilmu.com/pengertian-jenis-danmanfaat-rawa/ (diakses 11 Juli 2018)

Uhlig, H.H. W.R. Revie. 2000. Uhlig's Corrosion Handbook, John Wiley and Sons p.582. New York.

Wahjudi, Didik dan Roche Alimin. Rekayasa Mutu Besi Beton dengan Metode Taguchi. Jurnal Teknik Mesin Vol. 2, No. 2, Oktober 2000: 102 - 108

Widharto, Sri. 1999. Karat dan Pencegahannya. Jakarta: PT Pradnya Paramita. Wirarna, dkk. 2015. Analisa Kandungan Timbal pada Buah Apel (Pyrus Malus, L) yang dipajangkan dipinggir Jalankota Palu menggunakan Metode Spektrofotometri Serapan Atom . Jurnal of Natural Science Vol 4(1) : $32-45$. 